\title{
Investigation of natural durability of some native and exotic wood species against Hylotrupes bajulus (Cerambycidae) and Anobium punctatum (Anobiidae)
}

\author{
Mesut YALÇIN ${ }^{1}$, Cihat TAŞÇIOĞLU ${ }^{1}$, Rudy PLARRE ${ }^{2}$, Çağlar AKÇAY ${ }^{1 *}$, Sabine BUSWEILER ${ }^{2}$
}

${ }^{1}$ Duzce University, Faculty of Forestry, Department of Forest Products Engineering, 81620, Duzce, TURKEY

${ }^{2}$ Federal Institute for Materials Research and Testing (BAM), 12205, Berlin, GERMANY

*Corresponding author: caglarakcay@duzce.edu.tr

Received Date: 12.05 .2017

Accepted Date: 10.03 .2018

Abstract

Aim of study: In this study, natural durability of some domestic and foreign wood species against Hylotrupes bajulus and Anobium punctatum larvae were tested on laboratory scale

Area of study: This study was conducted at Department of Forest Products Engineering in Duzce University, Turkey and Federal Institute for Materials Research and Testing (BAM), Germany.

Material and Methods: Scotch pine (Pinus sylvestris), fir (Abies nordmanniana), spruce (Picea orientalis), cedar (Cedrus libani), poplar (Populus tremula) and beech (Fagus orientalis) woods were used to test H. bajulus larvae (EN 46-1). Alder (Alnus glutinosa), oak (Quercus cerris), poplar (Populus tremula), beech (Fagus orientalis), maple (Acer carpinifolium), ash (Fraxinus angustifolia), teak (Tectona grandis), ayous (Triplochiton scleroxylon), movingui (Distemonanthus benthamianus), dahoma (Piptadeniastrum africanum), iroko (Chlorophora excelsa), bubinga (Guibourtia tessmannii) and sapele (Entandrophragma cylindiricum) woods were used for A. punctatum larvae (EN 49-1). At the end of the experiment, the mortality rates of the larvae were determined and the size and weights of the surviving larvae were measured.

Main results: $F$. orientalis and $C$. libani were found to be the most resistant wood species against $H$. bajulus larvae while A. nordmanniana was the least resistant. All tropical wood species and oak and maple from domestic wood species showed $100 \%$ mortality rate therefore found to be the most resistant against A. punctatum larvae. The most vulnerable wood species was found to be alder with a $35 \%$ mortality.

Research highlights: while $F$. orientalis, $C$. libani, and $P$. tremula were found the most resistance wood species against $H$. bajulus, $P$. sylvestris and $A$. nordmanniana were determined as most vulnerable. All tropical wood species and two domestic species (Q. cerris and A. carpinifolium) showed the highest mortality rate as $100 \%$. The least durable domestic wood was determined as alder.

Keywords: Hylotrupes bajulus, Anobium punctatum, natural durability, tropical wood, native wood.

\section{Bazı yerli ve egzotik ağaç türü odunlarının Hylotrupes bajulus (Cerambycidae) ve}

\section{Anobium punctatum (Anobiidae) böceklerine karşı doğal dayanıklılıklarının araştırılması}

\section{Özet}

Çalışmanın amacı: Bu çalışmada bazı yerli ve yabancı ağaç türü odunlarının Hylotrupes bajulus ve Anobium punctatum larvalarına karşı doğal dayanıklılıkları laboratuvar ölçeğinde test edilmiştir

Çalışma alanı: Bu çalışma Düzce Üniversitesi Orman Endüstri Mühendisliği Bölüm Laboratuvarı ve Almanya Federal Materyal Araştırma ve Test Enstitüsü'nde (BAM) yürütülmüştür.

Materyal ve Yöntem: Çalışmada Hylotrupes bajulus larvalarına karşı sarıçam (Pinus sylvestris), göknar (Abies nordmanniana), ladin (Picea orientalis), sedir (Cedrus libani), kavak (Populus tremula) ve kayın (Fagus orientalis) odunları kullanılmıştır (EN 46-1). Anobium punctatum larvalarına karşı ise kızılağaç (Alnus glutinosa), meşe (Quercus cerris), kavak (Populus tremula), kayın (Fagus orientalis), akçaağaç (Acer carpinifolium), dişbudak (Fraxinus angustifolia), tik (Tectona grandis), ayos (Triplochiton scleroxylon), novengi (Distemonanthus benthamianus), dahoma (Piptadeniastrum africanum), iroko (Chlorophora excelsa), bubinga (Guibourtia tessmannii), sapelli (Entandrophragma cylindiricum) ağaç türü odunları kullanılmıştır (EN 49-1).

Sonuçlar: $H$. bajulus larvalarına karşı en dayanıklı ağaç türü odunlarının $F$. orientalis ve $C$. libani olduğu, en dayanıksız odun türünün ise A. nordmanniana olduğu belirlenmiştir. A. punctatum larvalarına karşı ise tropik ağaç türü odunlarının hepsi, yerli ağaç türü odunlarının ise \%100 ölüm oranı ile meşe ve akçaağaç en dayanıklı olarak belirlenmiştir. En dayanıksız odun türünün ise \%35 ölüm oranı ile kızılağaç olduğu görülmüştür.

Araştırma vurguları: $F$. orientalis, $C$. libani ve $P$. tremula $H$. Bajulus'a karşı en dayanıklı tür iken, $P$. sylvestris ve A. nordmanniana en dayanıksız tür olmuştur. A puntatum tüm egzotik türler, Q. cerris ve A. carpinifolium'da $\% 100$ ölüm oranı göstermiştir. En dayanıksız yerli tür ise kızılağaç olduğu görülmüştür.

Anahtar kelimeler: Hylotrupes bajulus, Anobium punctatum, doğal dayanıklılık, tropik odun, yerli odun 


\section{Introduction}

Wood material is one of the most used materials in our daily life. However, it is destroyed by insects when used unprotected. For this reason, such materials are impregnated with chemicals such as CCA (Chromated Copper Arsenate). However, in recent years, many of the toxic chemicals have been banned due to increased environmental pressures and environmental restrictions. Thus, it has been tried to use durable wood species for longer service life. In this case, however, proper harvesting practices should be considered (Schultz \& Nicholas, 2008).

$1,200,000$ insect species live throughout the world. Some of these insect species cause destruction in forests and forest products. The damage caused by insects varies according to the tree species. There are insects that are destructive for only coniferous or only broad leaved species, as well as in both wood species. Some of the insects that destroy tree and wood materials are larval form, while the others are adults.

Old house borer $H$. bajulus is one most important insect from Cerambycidae family that destroys the wood and timber structures (Chiappini, 2010). H. bajulus generally attacks to the coniferous woods such as pine, fir and spruce. On the other hand, it was stated that $H$. bajulus can cause damage on redwood, oak, ash, poplar and locust from broadleaved wood species. At first stages, H. bajulus feeds on sapwoods and later it penetrates to the heartwood. Old house borer larvae require sapwood with high protein content $(\% 0,2)$ for the development. Larval development occurs in sapwood faster than heartwood (Goodell, 2008). H. bajulus distributed widely over the world including Turkey.

The body of $H$. bajulus is decorated with yellowish gray thin hairs on a dark brown chestnut color, long and fairly flat. The antennas have 11 segments, thin and approximately half the length of the body. The eggs are yellowish white in color and approximately $2 \mathrm{~mm}$ long. It is known that $H$. bajulus sometimes lays 30-200 eggs, in some cases up to 300 within 3 days after mating. It takes 8-12 days to emerge from egg to larvae stage. The larva has light yellowish color and the length of mature larvae varies between 1830 mm (Çanakçığlu \& Mol, 1998).
A. punctatum is the other important insect that destroys the wood materials. It is also known as furniture beetle.

Cylindrical adults are 2.5-5.0 $\mathrm{mm}$ in length, reddish brown colored. They are covered with thin yellowish hairs. Mature females put their eggs in the old flying holes and cracks in the galleries. In general, $A$. punctatum adults do not lay eggs on smooth and polished surfaces. Generally, a female puts 1-2 eggs every time.

It is also observed that it can lay up to 80 eggs. The eggs are grown up to 34 weeks. The main food of larvae is cellulose. It need a small amount of protein. The time larvae to be become an adult depend on the quality of food and the climatic conditions. A. punctatum larvae live at least 2 years in the sapwood of deciduous trees and 4-8 years or longer in coniferous trees. The optimum temperature for growth of larvae is $22-23^{\circ} \mathrm{C}$ (lower than the house beetle). Wood moisture demands are around $30 \%$. With the decreasing in relative humidity, the destruction period of $A$. punctatum larvae are accelerated and larval development is accelerating. When the relative humidity is around $55-60 \%$, wood humidity is $10-12 \%$, the development of the larvae is over. During long periods of heat, there is no evidence of damage to this insect in areas with central heating systems (Kaygın, 2007).

It is distributed in the Marmara, Central Anatolia, Black Sea and Eastern Anatolia regions in Turkey. It causes damage on pine, spruce, poplar, beech, alder, walnut and ash. They prefer soft lumber woods. The larva develops in the heartwood of deciduous trees and the sapwood of coniferous trees. It has significant damage in wooden parts of buildings, such as beams, paneling, parquet, lathes, stair doors and various furniture materials and musical instruments (Kaygin, 2007).

There are limited publications on wood damage of these insects in Turkey. Erdem \& Çanakçığlu (1977) investigated the biology of wood destroying insects, their identification, characteristics; and methods of protection from these insects. Usually these works are limited to forest habitat and harvested or processed wood material. The subject has not been thoroughly researched. 
The aim of this study was to determine natural durability of some native and tropic wood species against $H$. bajulus and $A$. punctatum larvae.

\section{Material and Method Preparation of wood samples}

The wood samples were prepared according to the European Standards (EN 461, 2008; EN-47, 2004). The samples were cut $50 \times 25 \times 15 \mathrm{~mm}^{3}$ (longitudinal $\mathrm{x}$ radial $\mathrm{x}$ tangential) dimensions for $H$. bajulus and $A$. punctatum larval tests. All wood blocks were conditioned at $28 \pm 2{ }^{\circ} \mathrm{C}$ and $70 \pm 5 \%$ relative humidity for 4 weeks.

\section{H. bajulus larval tests}

One part of the tests was carried out in the division of Biodeterioration and Reference Organisms in Federal Institute for Materials Research and Testing (BAM), Berlin, Germany, the other part of the tests was done in Forest Biology and Wood Protection Technology Laboratory in Duzce University. Wood specimens were prepared for larval test. One glass plate as one side was placed on only one face of wood specimens to create a small gap to put larvae. The other surfaces were covered with paraffin wax. Newly hatched larvae obtained from end of cultivation were used for the durability test according to the EN 46-1 standard. A total of ten larvae were inserted between glass and wood surface $(\mathrm{Nt})$. After four weeks, the glasses were removed on the wood block surfaces and the living and dead larvae were recorded (not tunneled, started to tunnel, alive and tunneled) under a microscope. Then, the test continued until end of the eight weeks. At the end of the test, all wood blocks were cut and the live and dead larvae were determined. Larva mortality rates were calculated used these data. In addition, the standard (EN 46-1), larvae sizes and weights were measured using Stereo microscope and scales, respectively.

$$
\text { Mortality rate }(\%)=\frac{\mathrm{Nf}}{\mathrm{Nt}} \times 100
$$

In this Equation; Nt, number of total larvae inserted the surfaces of wood (10 replicates); $\mathrm{Nf}$, number of dead larvae after 12 weeks.

\section{A. punctatum larval tests}

A. punctatum larval tests were carried out in the division of Biodeterioration and Reference Organisms in Federal Institute for Materials Research and Testing (BAM), Berlin, Germany. The test specimens were kept in conditioning chamber for a minimum of two weeks. The egg-laying zones were prepared by attaching a piece of the fine cloth measuring approximately $45 \times 20 \mathrm{~mm}$ to face of test specimens. Recently emerged adults collected from laboratory cultured were used in the test. Each test specimen was placed in one of the test containers and five female and five male insects were added the containers covered with a disc of filter paper and placed in the testing chamber for approximately one week. After then the eggs were counted under microscope. If there were fewer than 50, added another group of insects to container (Table 1). At the end of the $52^{\text {nd }}$ weeks, the test specimens were cut and counted the number of live and dead larvae according to EN 49-1 standard. In addition, the standard (EN 49-1), larvae sizes were measured using a stereo microscope.

Mortality rate $(\%)=\frac{\mathrm{Nst}}{\mathrm{Ndl}} \times 100$

In this Equation: Nst is number of start the tunnel larva, $\mathrm{Ndl}$ is number of dead larva after 52 weeks. 
Table 1: Number of A. punctatum eggs on the test specimens

\begin{tabular}{|c|c|c|c|c|c|c|c|c|}
\hline \multirow{2}{*}{ Wood species } & \multicolumn{2}{|c|}{$\begin{array}{l}1^{\text {st }} \text { Introduction of } A . \\
\text { punctatum pairs }\end{array}$} & \multicolumn{2}{|c|}{$\begin{array}{c}2^{\text {nd }} \text { Introduction of } A . \\
\text { punctatum pairs }\end{array}$} & \multicolumn{2}{|c|}{$\begin{array}{l}3^{\text {th }} \text { Introduction of } A . \\
\text { punctatum pairs }\end{array}$} & \multicolumn{2}{|c|}{$\begin{array}{c}4^{\text {th }} \text { Introduction of } A . \\
\text { punctatum pairs }\end{array}$} \\
\hline & $\begin{array}{c}\text { Amount } \\
\text { of eggs } \\
\text { surface } 1\end{array}$ & $\begin{array}{c}\text { Amount } \\
\text { of eggs } \\
\text { surface } 2\end{array}$ & $\begin{array}{c}\text { Amount } \\
\text { of eggs } \\
\text { surface } 1\end{array}$ & $\begin{array}{c}\text { Amount } \\
\text { of eggs } \\
\text { surface } 2\end{array}$ & $\begin{array}{l}\text { Amount } \\
\text { of eggs } \\
\text { surface } 1\end{array}$ & $\begin{array}{c}\text { Amount } \\
\text { of eggs } \\
\text { surface } 2\end{array}$ & $\begin{array}{c}\text { Amount } \\
\text { of eggs } \\
\text { surface } 1\end{array}$ & $\begin{array}{c}\text { Amount } \\
\text { of eggs } \\
\text { surface } 2\end{array}$ \\
\hline \multirow{3}{*}{ A. glutinosa } & 25 & 49 & & & & & & \\
\hline & 21 & 17 & 71 & 67 & & & & \\
\hline & 92 & 18 & & & & & & \\
\hline \multirow{3}{*}{ Q. cerris } & 7 & 0 & 9 & 1 & 35 & 12 & 73 & 41 \\
\hline & 2 & 6 & 28 & 6 & 61 & 7 & & \\
\hline & 16 & 13 & 19 & 16 & 22 & 16 & 26 & 19 \\
\hline \multirow{3}{*}{ P. sylvestris } & 8 & 24 & 19 & 49 & & & & \\
\hline & 46 & 0 & 74 & 18 & & & & \\
\hline & 14 & 13 & 21 & 24 & 67 & 31 & & \\
\hline \multirow{3}{*}{ P. tremula } & 24 & 52 & & & & & & \\
\hline & 7 & 8 & 40 & 25 & & & & \\
\hline & 14 & 6 & 27 & 31 & & & & \\
\hline \multirow{3}{*}{ F. orientalis } & 8 & 20 & 8 & 22 & 16 & 23 & 26 & 28 \\
\hline & 19 & 4 & 51 & 10 & & & & \\
\hline & 6 & 5 & 27 & 19 & 47 & 23 & & \\
\hline \multirow{3}{*}{ A. carpinifolium } & 107 & 39 & & & & & & \\
\hline & 32 & 1 & 71 & 2 & & & & \\
\hline & 48 & 63 & & & & & & \\
\hline \multirow{3}{*}{ F. angustifolia } & 32 & 33 & & & & & & \\
\hline & 0 & 4 & 13 & 6 & 24 & 23 & 37 & 27 \\
\hline & 28 & 10 & 67 & 29 & & & & \\
\hline \multirow{3}{*}{ T. grandis } & 5 & 0 & 7 & 0 & 18 & 0 & 32 & 1 \\
\hline & 0 & 0 & 0 & 1 & 9 & 7 & 23 & 17 \\
\hline & 1 & 0 & 6 & 0 & 32 & 0 & 57 & 6 \\
\hline \multirow{3}{*}{ T. scleroxylon } & 16 & 15 & 16 & 19 & 34 & 63 & & \\
\hline & 8 & 15 & 28 & 28 & & & & \\
\hline & 8 & 11 & 27 & 29 & & & & \\
\hline \multirow{3}{*}{ D. benthamianus } & 12 & 16 & 16 & 22 & 21 & 42 & & \\
\hline & 5 & 8 & 62 & 18 & & & & \\
\hline & 11 & 8 & 52 & 46 & & & & \\
\hline \multirow{3}{*}{ P. africanum } & 3 & 5 & 6 & 11 & 25 & 17 & 33 & 28 \\
\hline & 4 & 0 & 14 & 9 & 134 & 31 & & \\
\hline & 21 & 5 & 33 & 32 & & & & \\
\hline \multirow{3}{*}{ T. excelsa } & 9 & 3 & 22 & 15 & 40 & 45 & & \\
\hline & 1 & 5 & 15 & 31 & 23 & 73 & & \\
\hline & 0 & 3 & 44 & 6 & & & & \\
\hline \multirow{3}{*}{ G. tessmannii } & 32 & 15 & 44 & 41 & & & & \\
\hline & 3 & 2 & 21 & 23 & 31 & 42 & & \\
\hline & 9 & 12 & 22 & 28 & & & & \\
\hline \multirow{3}{*}{ E. Cylindiricum } & 28 & 16 & 25 & 21 & 114 & 78 & & \\
\hline & 17 & 0 & 40 & 13 & & & & \\
\hline & 20 & 7 & 68 & 17 & & & & \\
\hline
\end{tabular}

\section{Results and Discussion \\ H. bajulus larval tests}

According to the findings obtained, it was observed that at the end of 4 weeks of incubation period, all $H$. bajulus larvae tunneled on $A$. nordmanniana, $P$. sylvestris and $P$. orientalis wood and were alive based on microscope investigations. In P. tremula,
$F$. orientalis and C. libani wood, it has seen that maximum half of the total number of larvae placed in the specimens was tunneled and alive. Especially at the end of the first four weeks in the $C$. libani wood, the larvae seem to have died before they opened the tunnel. At the end of the four weeks experimental period, larvae of A. nordmanniana, $P$. sylvestris and 
P. orientalis wood were found to be $90 \%$ or more alive, while the mortality rate of $P$. tremula, $F$. orientalis and $C$. libani species was $50 \%$ or more (Table 2).

At the end of the experiment for 4 weeks with live larvae was continued until the $12^{\text {th }}$ week as stated in the standard. At the end of this period, the lowest mortality rate was determined as $16.6 \%$ in A. nordmanniana wood. In addition, mortality rates were recorded $23.3 \%$ and $56.7 \%$ for P. sylvestris and $P$. orientalis, respectively. However, there was no statistically significant difference between the mean death rate of $P$. sylvestris wood and the mean mortality rate of A. nordmanniana larvae. In $C$. libani, $P$. tremula and $F$. orientalis wood specimens, over $95 \%$ mortality rate was observed. These differences in the mean mortality rates of wood species were statistically significant $(\mathrm{P}$ $<0.05)$. The high mortality rate in cedar wood can be explained by the amount of $13 \%$ extractive matter soluble in ethanol that is naturally effective against insects (Bozkurt \& Erdin, 1989).

Table 2: Natural durability of softwood according to EN 46-1 against $H$. bajulus

\begin{tabular}{|c|c|c|c|c|c|c|c|c|}
\hline \multirow{2}{*}{ Wood species } & \multicolumn{2}{|c|}{$\begin{array}{c}\text { Dead larvae on } \\
\text { surface after } 4 \\
\text { weeks }\end{array}$} & \multicolumn{2}{|c|}{$\begin{array}{c}\text { Live larvae on } \\
\text { surface after } 4 \\
\text { weeks }\end{array}$} & \multicolumn{4}{|c|}{$\begin{array}{c}\text { Number of live/dead larvae } \\
\text { after } 12 \text { weeks }\end{array}$} \\
\hline & $\begin{array}{c}\text { not } \\
\text { tunnel } \\
\text { ed }\end{array}$ & $\begin{array}{l}\text { started } \\
\text { to } \\
\text { tunnel }\end{array}$ & $\begin{array}{l}\text { alive and } \\
\text { tunneled }\end{array}$ & $\begin{array}{c}\text { mortality } \\
\text { (surface) } \\
\%\end{array}$ & live & dead & $\begin{array}{l}\text { Mortality } \\
\text { rate }(\%)\end{array}$ & $\begin{array}{l}\text { Mean mortality } \\
\text { rate }(\%)\end{array}$ \\
\hline \multirow{3}{*}{ A. nordmanniana } & 0 & 0 & 10 & 0 & 8 & 2 & 20 & \multirow{3}{*}{$16.6 a^{*}$} \\
\hline & 0 & 0 & 10 & 0 & 10 & 0 & 0 & \\
\hline & 0 & 1 & 9 & 10 & 7 & 3 & 30 & \\
\hline \multirow{3}{*}{ P. sylvestris } & 0 & 0 & 10 & 0 & 7 & 3 & 30 & \multirow{3}{*}{$23.3 a$} \\
\hline & 0 & 1 & 9 & 10 & 8 & 2 & 20 & \\
\hline & 0 & 1 & 9 & 10 & 8 & 2 & 20 & \\
\hline \multirow{3}{*}{$P$. orientalis } & 0 & 0 & 10 & 0 & 3 & 7 & 70 & \multirow{3}{*}{$56.7 b$} \\
\hline & 0 & 1 & 9 & 10 & 8 & 2 & 20 & \\
\hline & 0 & 0 & 10 & 0 & 2 & 8 & 80 & \\
\hline \multirow{3}{*}{ C. libani } & 8 & 2 & 2 & 80 & 0 & 0 & 100 & \multirow{3}{*}{$100 c$} \\
\hline & 10 & 0 & 0 & 100 & 0 & 0 & 100 & \\
\hline & 9 & 1 & 0 & 100 & 0 & 0 & 100 & \\
\hline \multirow{3}{*}{ P. tremula } & 8 & 2 & 1 & 90 & 0 & 0 & 100 & \multirow{3}{*}{$96.7 c$} \\
\hline & 5 & 5 & 4 & 60 & 2 & 1 & 90 & \\
\hline & 4 & 6 & 5 & 50 & 0 & 0 & 100 & \\
\hline \multirow{3}{*}{ F. orientalis } & 4 & 6 & 3 & 70 & 0 & 0 & 100 & \multirow{3}{*}{$100 c$} \\
\hline & 5 & 5 & 3 & 70 & 0 & 0 & 100 & \\
\hline & 5 & 5 & 4 & 60 & 0 & 0 & 100 & \\
\hline
\end{tabular}

*The same letters written in italic are not different each other statically.

As it is known, $P$. sylvestris is the most preferred wood species for $H$. bajulus (Chen et al. 2005). However, as it can be seen from the table, at the end of 12 weeks test period, the larvae found alive was slightly higher (6\%) in A. nordmanniana wood. On the other hand, larvae weights and sizes measured at the end of the experiment showed different results. Based on the results showing in table 3 , the mean larvae weight found in $P$. sylvestris was $2,6 \mathrm{mg}$, whereas the mean larvae weight obtained from A. nordmanniana wood was $1,9 \mathrm{mg}$. According to current findings, while the survival rate of larvae was found to be higher in A. nordmanniana wood, the mean larvae weight was lower $(1,9 \mathrm{mg})$ than the mean larvae weight in P. sylvestris. This difference was also statistically significant $(\mathrm{P}<0.05)$.

Sivrikaya et al. (2015) conducted with $P$. sylvestris, $P$. orientalis, $F$. angustifolia, $C$. excelsa and Erythrophleum suaveolens woods and they recorded that $16,7 \%$ mortality rate in P. sylvestris and 33,3\% in P. orientalis at 
the end of the 24 weeks test result while 100 $\%$ mortality rate observed in $F$. angustifolia, $C$. excelsa and E. suaveolens woods. They stated that mortality rates were high due to these woods are highly durable to $H$. bajulus . For this reason, our results are similar with previous literature results.

Table 3: Larval sizes and weights of $H$. bajulus larvae

\begin{tabular}{|c|c|c|c|c|c|c|}
\hline \multirow[b]{2}{*}{ Wood species } & \multicolumn{6}{|c|}{ Larval sizes and weight } \\
\hline & $\begin{array}{l}\text { Width } \\
(\mathrm{mm})^{*}\end{array}$ & $\begin{array}{l}\text { Length } \\
(\mathrm{mm})^{*}\end{array}$ & $\begin{array}{c}\text { Weight } \\
\text { (gr)* }\end{array}$ & $\begin{array}{l}\text { Mean } \\
\text { width } \\
(\mathrm{mm})\end{array}$ & $\begin{array}{l}\text { Mean } \\
\text { length } \\
(\mathrm{mm})\end{array}$ & $\begin{array}{c}\text { Mean } \\
\text { weight } \\
\text { (gr) }\end{array}$ \\
\hline \multirow{3}{*}{ A. nordmanniana } & 0.5 & 2.14 & 1.9 & \multirow{3}{*}{$0.50 a$} & \multirow{3}{*}{$2.13 a b$} & \multirow{3}{*}{$1.9 a$} \\
\hline & 0.51 & 2.09 & 1.9 & & & \\
\hline & 0.49 & 2.17 & 2 & & & \\
\hline \multirow{3}{*}{ P. sylvestris } & 0.57 & 2.64 & 2.4 & \multirow{3}{*}{$0.57 a$} & \multirow{3}{*}{$2.64 b$} & \multirow{3}{*}{$2.6 b$} \\
\hline & 0.57 & 2.62 & 2.5 & & & \\
\hline & 0.58 & 2.66 & 2.8 & & & \\
\hline \multirow{3}{*}{ P. orientalis } & 0.51 & 2.23 & 1.8 & \multirow{3}{*}{$1.81 a$} & \multirow{3}{*}{$1.42 a$} & \multirow{3}{*}{$2 a$} \\
\hline & 2.45 & 0.532 & 2.2 & & & \\
\hline & 2.48 & 1.5 & 2 & & & \\
\hline
\end{tabular}

* Average of five larvae for each test specimens

\section{A. punctatum larval tests}

Findings of A. punctatum larvae tests on 13 different local and foreign wood species are shown in Table 4 . After 52 weeks, the mean mortality rates of live and dead larvae were calculated. The highest larval survival rate among the wood species was determined as $65 \%$ in A. glutinosa wood. In addition, survival rate of $35 \%$ in $P$. tremula, $32 \%$ in $F$. orientalis and $10 \%$ in $F$. angustifolia were detected. Larvae have begun to open tunnels in certain numbers in domestic wood species, and in Q. cerris and A. carpinifolium wood at the end of 1 year experiment period. When these tunnels were examined, the mean depth of the tunnels on $Q$. cerris is approximately 2.5-3 mm while and the depth of the tunnels on the A. carpinifolium is about $2-2.5 \mathrm{~mm}$. However, mortality rates of larvae were $100 \%$ in Q. cerris and A. carpinifolium wood species (Table 4).

When the results of the A. punctatum larva test on 7 different tropical wood species were examined, it was observed that the larvae were trying to open the tunnel at the beginning and these tunnels were about $0.5-1 \mathrm{~mm}$ in all wood species. However, at the end of the 52-weeks experimental period, no live larvae were found in the specimens under microscope investigation. Thus, larval mortality rates were calculated as $100 \%$. 
Table 4 . Mean mortality rate of A. punctatum

\begin{tabular}{lccccc}
\hline Wood species & $\begin{array}{c}\text { Total number of } \\
\text { eggs (number) }\end{array}$ & $\begin{array}{c}\text { Started to } \\
\text { tunnel }\end{array}$ & $\begin{array}{c}\text { Number of live } \\
\text { larvae retrieved } \\
\text { (number) }\end{array}$ & $\begin{array}{c}\text { Number of } \\
\text { dead larvae } \\
\text { (number) }\end{array}$ & $\begin{array}{c}\text { Mortality rate } \\
(\%)\end{array}$ \\
\hline A. glutinosa & 107 & 60 & 39 & 21 & 35 \\
\hline Q. cerris & 76 & 32 & 0 & 32 & 100 \\
\hline$P$. tremula & 66 & 57 & 20 & 37 & 65 \\
\hline F. orientalis & 62 & 28 & 9 & 19 & 68 \\
\hline A. carpinifolium & 110 & 40 & 0 & 40 & 100 \\
\hline F. angustifolia & 75 & 49 & 5 & 44 & 90 \\
\hline T. grandis & 45 & 37 & 0 & 37 & 100 \\
\hline T. scleroxylon & 70 & 49 & 0 & 49 & 100 \\
\hline D. benthamianus & 80 & 56 & 0 & 56 & 100 \\
\hline P. africanum & 97 & 38 & 0 & 38 & 100 \\
\hline C.excelsa & 77 & 62 & 0 & 62 & 100 \\
\hline G. tessmannii & 69 & 29 & 0 & 29 & 100 \\
\hline E. Cylindiricum & 110 & 43 & 0 & 43 & 100 \\
\hline
\end{tabular}

After the experiment, various microscopic measurements were carried out on the larvae in order to determine the development levels of living ones (Table 5). When the mean lengths of larvae were examined, it was found that the highest mean larval length was 2.35 $\mathrm{mm}$ and emerged from A. glutinosa wood. The lowest mean larvae length was observed as $2.18 \mathrm{~mm}$ in $P$. tremula wood. When the mean of the measurements taken from the head, thorax and abdomen (last part of the abdomen segment) part of the larvae were compared, the highest mean width was measured as $0.73 \mathrm{~mm}$ on the larvae extracted in the A. glutinosa wood. According to these findings, there is a linear relationship between the larval development and the rate of viability of $A$. punctatum in alder wood. Although the rate of viability of $A$. punctatum was $35 \%$ in $P$. tremula wood, larval development is seen to be much lower when comparing to the other wood species. The lower mortality rate can be explained in two ways; first lower extractive content of $P$. tremula wood and secondly low density of wood itself. Both of these features might help reducing mortality in P. tremula wood. The lack of larval development, on the other hand, might be related to amount of nutrients which plays important role in larval nourishment. The higher amount of extractives in tropical wood species is believed to be main reason for high mortality rate for A. punctatum.

According to previous literature, the development of Anobium larva is affected from type of the wood species, the chemical composition of the wood (Terzi et al., 2012), the amount and type of co-substances (starch, protein etc.) in the wood, the amount and type of the active substance. For this reason, larval development and mortality rates among wood species are different. In addition, although the effect of environmental factors (temperature, humidity) on larval development is important (Kaygin \& Sade, 2004; Pinniger \& Child 1996), the effect of these factors is minimized for both A. punctatum and $H$. bajulus as the environmental conditions were kept constant during this study.

According to the results obtained, Q. cerris wood showed significant natural resistance against $A$. punctatum larvae. This is somewhat interesting since $Q$. cerris wood (especially, sessile oak and pedunculate oak) was stated as a reference wood in EN49-1 standard. $Q$. cerris, on the other hand, showed very high natural durability (100\% mortality rate) which might be explained with its relatively high silica content (Sarıbaş, 2017). Silica might interrupt feeding behavior of A. punctatum. Therefore, $Q$. cerris wood is highly recommended if A. punctatum infestation risk is high. 
Table 5: Larval sizes of A. punctatum

\begin{tabular}{lccccc}
\hline \multirow{2}{*}{ Wood species } & $\begin{array}{c}\text { Mean larvae length } \\
(\mathrm{mm})\end{array}$ & \multicolumn{4}{c}{ Width $(\mathrm{mm})$} \\
\cline { 3 - 6 } & 2.35 & 0.58 & 0.73 & 0.89 & 0.73 \\
\hline A. glutinosa & 2.18 & 0.43 & 0.52 & 0.64 & 0.53 \\
\hline P. tremula & 2.29 & 0.46 & 0.57 & 0.73 & 0.59 \\
\hline F. orientalis & 2.28 & 0.44 & 0.56 & 0.70 & 0.56 \\
\hline F. angustifolia & & & & &
\end{tabular}
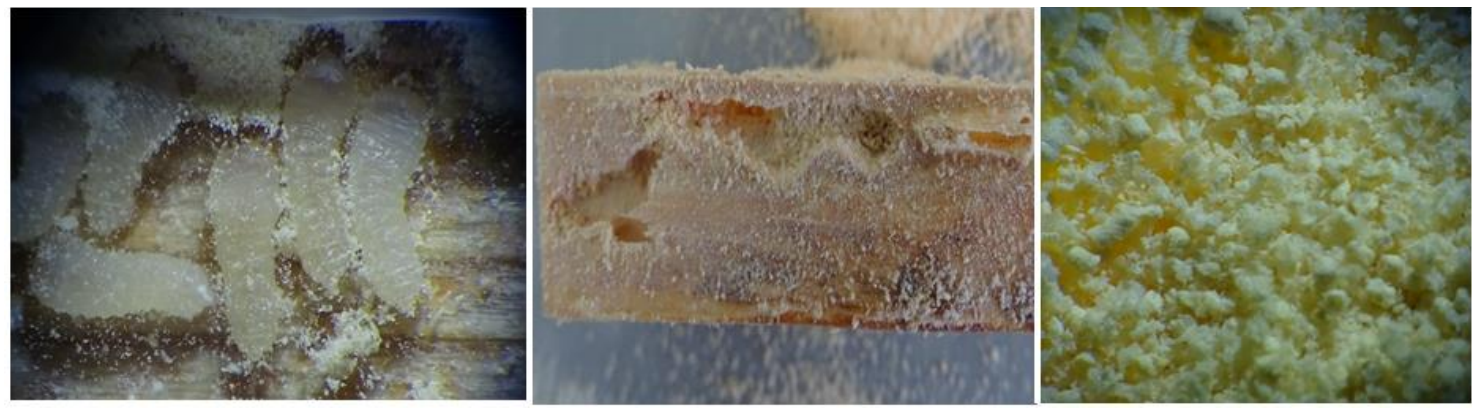

Figure 1. H. bajulus larvae attempting to open a tunnel, larvae defecation traces and feces
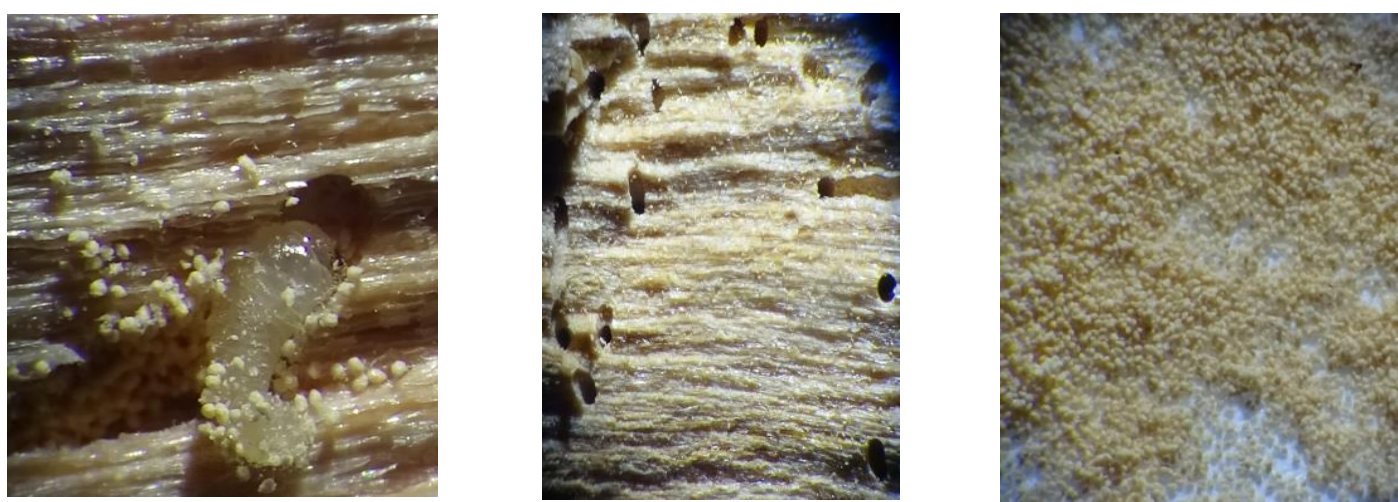

Figure 2. A. punctatum larvae damaging, larvae entrance holes and feces

\section{Conclusions}

The natural durability of native and tropical wood species, which are heavily used in the furniture industry against $H$. bajulus and A. punctatum were evaluated.

According to current results, while $F$. orientalis, C. libani, and $P$. tremula were found the most resistance wood species against $H$. bajulus, $P$. sylvestris and $A$. nordmanniana were determined as most vulnerable. After 12 weeks test period, the mortality of larvae was found lowest for $A$. nordmanniana wood while the largest sizes and weights of live larvae were measured in $P$. sylvestris wood.

All tropical wood species and two domestic species ( $Q$. cerris and $A$. carpinifolium) showed the highest mortality rate as $100 \%$. The least durable domestic wood was determined as alder. When sizes of A. punctatum larvae examined a linear relationship was recorded between sizes, weight and viability rates.

\section{Acknowledgement}

This study was supported by TÜBİTAKCOST project number of 1140850 .

\section{References}

Bozkurt, Y., \& Erdin, N. (1989). Ticarette önemli yabancl ăgaç türleri. İstanbul Üniversitesi Fen Bilimleri Enstitüsü Yayınları, İstanbul.

Chen, Z., White M.S., Robinson, W.H. (2005). Low-pressure vacuum to control larvae of Hylotrupes bajulus (Coleoptera: 
Cerambycidae). Proceedings of the fifth international conference on urban pests. In Lee C \& Robinson W.H. (ed). Printed by Perniagaan Ph'ng @ P\&Y Design Network, Malaysia.

Chiappini, E., Molinari, P., Busconi, M. Callegari, M., Fogher, C., \& Bani, P. (2010). Hylotrupes bajulus (L.) (Col. Cerambycidae): nutrition and attacked material. $10^{\text {th }}$ International Working Conference on Stored Product Protection. 27 June-2 July 2010), Volume 425, 97 103, Estoril, Portugal.

Çanakçığlu, H., \& Mol, T. (1998). Orman Entomolojisi: Zararlı ve Yararlı Böcekler. İstanbul Üniversitesi Orman Fakültesi Yayınları, İstanbul.

EN 47. (2004). Wood preservatives Determination of the toxic values against larvae of Hylotrupes bajulus (Linnaeus) (Laboratory method).

EN 49-1. (2006). Wood preservatives Determination of the protective effectiveness against Anobium punctatum (De Geer) by egg-laying and larval survival - Part 1: Application by surface treatment (Laboratory method).

EN113. (1996). Wood preservatives. Test method for determining the protective effectiveness against wood destroying basidiomycetes - determination of toxic values.

EN46-1. (2008). Wood preservativesdetermination of the preventive action against recently hatched larvae of Hylotrupes bajulus (Linnaeus) - Part 1: Application by Surface Treatment (Laboratory Method).

Erdem, R., \& Çanakçığlu, H. (1977). Türkiye odun zararlıları. İstanbul Üniversitesi Orman Fakültesi yayınları, Istanbul.

Goodell B., Qian Y., \& Jellison J. (2008). Fungal decay of wood: soft rot - brown rot - white rot: Pages 9-31 in T.P. Schultz, H. Militz, M.H. Freeman, B. Goodell, \& D.D. Nicholas (eds), Development of Commercial Wood Preservatives:
Efficacy, Environmental, and Health Issues. Chapter 1, American Chemical Society Symposium Series 982, Washington, DC.

Kaygın, T. (2007). Endüstriyel odun zararllart, Nobel yayın No: 1082. ISBN 978-9944-77-084-2

Kaygın, T., Sade, E. (2004). Species of Anobiidae family in Turkey and introduction of some important ones of these species. ZKÜ Journal of Bartın Forest Faculty, 6(6), 141-152.

Pinniger, D.B., \& Child, R.E. (1996). Woodworm-a necessary case for treatment? New techniques for the detection and control of furniture beetle. Proceedings of the Second International Conference on Urban Pests in the Urban Environment, Edinburgh, Scotland.

Sarıbaş, M. (2017). Serbest orman mühendisleri için ders notu. Retrieved fromhttp://ormuh.org.tr/arsiv/files/GYMN OSPERMAE\%20Bolum\%20\%28I\%29.pd f. (Accessed on 11 May 2017).

Schultz, T.P., \& Nicholas, D.D. (2008). Introduction to developing wood preservative systems and molds in homes. Pages $2-8$ in Schultz T.P., Militz, H., Freeman M.H., Goodell B., \& Nicholas, D.D., (eds); Development of Commercial Wood Preservatives: Efficacy, Environmental, and Health Issues. Chapter 1, American Chemical Society Symposium Series 982, Washington, DC.

Sivrikaya H., Can A., Troya T., \& Conde, M. (2015). Comparative biological resistance of differently thermal modified wood species against decay fungi, Reticulitermes grassei and Hylotrupes bajulus. Maderas. Ciencia y Tecnolog. 17 (3):559-567.

Terzi, E., Kartal, S.N., Ibáñez, CM., Köse, C., Arango, R., Clausen, CA., \& Green, F. (2012). Biological performance of Liquidambar orientalis Mill. heartwood. International Biodeterioration \& Biodegradation, 75, 104-108. 